\title{
Aerobic stability, chemical composition and ruminal degradability of sugarcane silage with glycerin from biodiesel
}

\author{
Estabilidade aeróbia, composição química e degradabilidade \\ ruminal da cana-de-açúcar ensilada com glicerina de biodiesel
}

\author{
Marco Antonio Bensimon Gomes ${ }^{1 *}$; Gentil Vanini de Moraes $^{2}$; \\ Clóves Cabreira Jobim²; Tatiana Carlesso dos Santos²; \\ Marcos Rogério Oliveira ${ }^{1}$; Robson Marcelo Rossi ${ }^{3}$
}

\begin{abstract}
The experiment was performed with the objective of studying the ensiled sugarcane silage with 0,5 , 10,15 and $20 \%$ of glycerin in experimental PVC silos. The aerobic stability was assessed by measuring the $\mathrm{pH}$ and the temperature of the silage at $0,24,48,72,96$ and $120 \mathrm{~h}$. The chemical composition, the levels of non-fiber carbohydrates (NFC) and the total digestible nutrients (TDN) were evaluated. The in vitro digestibility of dry matter (IVDDM) and the in vitro digestibility of the cell wall (IVDCW) in the silages were evaluated. In three fistulated cattle the in situ degradability of dry matter (DM) and the disappearance percentage of the neutral detergent fiber (NDF) in samples incubated at $0,2,6,12,24$, 48, 72 and $96 \mathrm{~h}$ were analyzed. The experimental design was completely randomized and the statistical analyzes were done using Bayesian inference. Increases were observed in DM, TDN, mineral matter, NFC and reductions in NDF, acid detergent fiber, crude protein and ether extract as the inclusion of glycerin was higher. IVDDM increased $(\mathrm{P}<0.05)$ in silage with 15 and $20 \%$ of glycerin in relation to those with 0,5 and $10 \%$. The IVDCW at levels of 10,15 and $20 \%$ of glycerin was higher $(\mathrm{P}<0.05)$ compared to the other treatments. Increases were observed in the soluble portion (a), a reduction in the insoluble fraction (b), and an increase in the degradability fraction constant (c) of the silages with $5,10,15$ and $20 \%$ of glycerin $(\mathrm{P}<0.05)$ compared to the control. Glycerin improved aerobic stability while maintaining a low $\mathrm{pH}$ and temperature during the observation period at levels of 15 and $20 \%$ of glycerin against the silage with 0,5 and $10 \%$. These results indicate glycerin as a promising additive for sugarcane silage, being able to enhance energy density and improve the aerobic stability of the ensiled matter when its inclusion is from 10 to $20 \%$.

Key words: Energy, glycerol, in vitro digestibility, non-fibrous carbohydrates, silage $\mathrm{pH}$, temperature of silage
\end{abstract}

\section{Resumo}

Objetivou-se estudar a silagem de cana-de-açúcar ensilada com 0, 5, 10, 15 e 20\% de glicerina em silos experimentais de PVC. Avaliou-se a estabilidade aeróbia medindo-se o $\mathrm{pH}$ e a temperatura da massa ensilada em 0, 24, 48, 72, 96 e 120h. Avaliaram-se a composição química, os teores de carboidratos não fibrosos (CNF) e nutrientes digestíveis totais (NDT). Avaliaram-se a digestibilidade in vitro da matéria seca (DIVMS) e da parede celular (DIVPC) das silagens. Em três bovinos fistulados avaliou-se a degradabilidade in situ da matéria seca (MS) e a porcentagem de desaparecimento da fibra em detergente

\footnotetext{
1 Discentes de Doutorado em Zootecnia, Universidade Estadual de Maringá UEM, Maringá PR, Brasil. E-mail: marcobensimon@ hotmail.com; oliveira.marcos.r@gmail.com

2 Profs., Dept ${ }^{\circ}$ de Zootecnia, UEM, Maringá, PR, Brasil. E-mail: gvmoraes@uem.br; ccjobim@uem.br; tcsantos@uem.br

3 Prof., Dept ${ }^{\circ}$ de Estatística, UEM, Maringá, PR, Brasil. E-mail: rmrossi@uem.br

* Author for correspondence
} 
neutro (FDN) em amostras incubadas em 0, 2, 6, 12, 24, 48, 72 e 96h. O delineamento experimental foi inteiramente casualisado e as análises estatísticas realizadas por meio de Inferência Bayesiana. Observaram-se aumentos na MS, NDT, matéria mineral, CNF e a redução de FDN, fibra em detergente ácido, proteína bruta e extrato etéreo à medida que a inclusão da glicerina foi maior. Houve aumento na DIVMS nas silagens com 15 e $20 \%$ de glicerina em relação às com 0,5 e $10 \%$. A DIVPC nos teores de 10, 15 e $20 \%$ de glicerina foi maior em relação aos outros tratamentos. Foram observados aumentos na porção solúvel (a), redução da fração insolúvel (b) e aumento da constante de degradabilidade da fração (c) das silagens com 5, 10, 15 e 20\% de glicerina em relação ao controle. A glicerina melhorou a estabilidade aeróbia, mantendo o $\mathrm{pH}$ e temperatura baixos no período de observação nos teores de $15 \mathrm{e}$ $20 \%$ de glicerina em relação as silagens com 0,5 e 10\%. Esses resultados indicam a glicerina como um promissor aditivo para silagens de cana-de-açúcar, sendo capaz de enriquecer a densidade energética e melhorar a estabilidade aeróbia do material ensilado a partir de uma inclusão de 10 a $20 \%$.

Palavras-chave: Carboidratos não fibrosos, digestibilidade in vitro, energia, glicerol, $\mathrm{pH}$ da silagem, temperatura da massa ensilada

\section{Introduction}

Sugarcane (Saccharum officinarum L.) is an alternative supplementation during periods of pasture scarcity ideal for presenting its ideal cut point in the dry season, which coincide with the period of lower tropical grasses productivity. Besides the low cost of production and high mass production per hectare, its use can be extended for four to five years, without renewal of the planting area. Sugar cane is used in small and large farms as forage for cattle feed during the drought offered in natura in daily cuts or ensiled (SIQUEIRA et al., 2007), but the best production is concentrated in the dry season, making sugar cane ensiling an interesting alternative.

In the ensiling process, the high content of soluble sugars from sugarcane leads to rapid proliferation of yeast with ethanol and carbon dioxide production and dry matter loss (McDONALD; HENDERSON; HERON, 1991). The same authors reported that the losses in the ensiling process can reach values of $40 \%$. Pedroso et al. (2005), studying the dynamics of fermentation of the sugar cane variety RB 835486, found DM losses until the 45th day after ensiling, reaching an average of $30 \%$ of total DM of the silage and from there keeping constant until 180 days of fermentation.

After opening the silo, fermentation starts that will be more intense the better the quality of silage, due to higher levels of carbohydrates, soluble residuals and lactic acid (JOBIM; GONÇALVES, 2003). According to the same authors when the silage is in contact with oxygen, it facilitates the action of spoilage microorganisms, reducing soluble sugars, organic acids, energy content, raising the $\mathrm{pH}$, reducing digestibility and consequently deteriorated silage may lead the great economic losses and low animal performance. Thus, in an attempt to improve the aerobic stability of silages, strategies like the use of inoculants containing heterofermentative bacteria have been studied. Considering the alcoholic fermentation that occurs in the ensiled sugar cane, there is the need to make use of additives which control ethanol production (NUSSIO et al., 2003).

The research of the use of biodiesel from glycerin as a component in animal feed has advanced and due to the high production of biodiesel and glycerin surplus, byproduct of high energy content, its addition in sugar cane silages could offset energetic losses caused by the ensiling process, facilitating the treatment of animals (SANTOS et al., 2014). The same authors found that the addition of $10 \%$ of glycerin reduced the population of clostridia in silage

This study aimed to evaluate the effects of adding five levels $(0,5,10,15$ and $20 \%)$ of semipurified glycerin to sugar cane silages and also evaluate the chemical composition, ruminal degradability, in vitro digestibility and aerobic stability of silages. 


\section{Material and Methods}

The experiment was conducted at the Experimental Farm of Iguatemi - State University of Maringá (UEM), Paraná, located at $23^{\circ} 25^{\prime}$ south latitude, and $51^{\circ} 57^{\prime}$ 'west longitude of Greenwich and $550 \mathrm{~m}$ of altitude and chemical analyzes were performed at the Animal Nutrition Laboratory of the Department of Animal Science at UEM (LANA) between May 2011 and May 2012.

The sugarcane used in the experiment was the RB 855536 variety and it was manually planted in February 2010 using six stems with three buds per meter, distributed in furrows, with fertilizer according to the soil analysis. The cut was performed on May 16, 2011 with a JF $92 Z 10$ silage cutter machine, adjusted for average particle size of $10 \mathrm{~mm}$. After cutting, the material was taken to a covered shed cemented and covered with plastic tarp which was distributed into five portions of $100 \mathrm{~kg}$ and then semi-purified glycerin from biodiesel was added in the proportions of $0,5,10,15$ to $20 \%$ (based on natural matter) and manually homogenized. The material was ensiled in experimental PVC silos, with $20 \mathrm{~cm}$ in diameter and $40 \mathrm{~cm}$ high, with an average specific mass of $600 \mathrm{~kg} / \mathrm{m}^{3}$, and then closed with polypropylene plastic canvas and sealed with tape. Four replications were made for each level of glycerin inclusion, totalizing 20 experimental silos.

The medium purity glycerin from the production of biodiesel from soybean oil was acquired in the company TCS-Meridional (Ponta Grossa - PR), and analyzed by the Institute of Technology of Paraná Biofuels Division (Tecpar), Curitiba. The chemical composition of glycerin used in the silage contained $82.54 \%$ of glycerol, $10.23 \%$ of water, $120 \mathrm{ppm}$ of methanol, $1.3 \%$ of sodium, $7.4 \%$ of ashes and its $\mathrm{pH}$ was 5.8.

The experimental silos were opened and $15 \mathrm{~cm}$ of the upper part was discarded. A sample of $1 \mathrm{~kg}$ was collected from each silo and dried in an oven with forced ventilation at $55^{\circ} \mathrm{C}$ for $72 \mathrm{~h}$ and grounded in a $2 \mathrm{~mm}$ mesh sieve in a "Willey" mill and stored in hermetic plastic pots, identified for further analyses.

The sugarcane silage remaining in the silos were exposed to air, covered with tulle type fabric, which had the potential hydrogen $(\mathrm{pH})$ and temperature of the ensiled mass (TEM) values read. The $\mathrm{pH}$ and TEM measurements were performed at the opening of the silos and then every 24 hours at times: 0, 24, $48,72,96$ and $120 \mathrm{~h}$ to assess the aerobic stability of the material. The $\mathrm{pH}$ were measured using a bench top digital $\mathrm{pH}$ meter from aqueous extract of the silage (CHERNEY; CHERNEY, 2003). TEM of the air exposed silage was measured with a digital thermometer with a Gulterm 180 ( ) penetration probe (Gulton, São Paulo), placed in the geometric center of the silage mass of each experimental silo. Ambient temperature, taken as reference, was recorded at the same time the $\mathrm{pH}$ and TEM were measured. The dry matter (DM), crude protein $(\mathrm{CP})$, ether extract (EE), mineral matter (MM), (AOAC, 1990), neutral detergent fiber (NDF) and acid detergent fiber (ADF) contents were determined in the samples (VAN SOEST; ROBERTSON; LEWIS, 1991). The in vitro digestibility of the dry matter (IVDDM) and the in vitro digestibility of the cell wall (IVDCW) were also determined. The IVDCW was calculated by the difference between the incubated NDF and the residue left after determining the NDF of the incubated material.

For the determination of the IVDCW and IVDDM, samples of approximately $0.25 \mathrm{~g}$ were weighed and placed in sealed bags (F57) previously washed with acetone and then incubated at $39.5^{\circ} \mathrm{C}$ using the in vitro incubator TE-150 (Tecnal ${ }^{\circledR}$ ) in accordance with Goering and Van Soest (1970). The inoculant liquid was obtained from castrated Holstein bovine, fitted with rumen cannula receiving diet based on sugarcane silage.

The total digestible nutrients (TDN) content was estimated by the equation:TDN (\%) = IVDDM+ $(1.25 * \mathrm{EE})-\mathrm{MM}$, and non-fiber carbohydrates (NFC) content was calculated by the equation NFC $=100-(\mathrm{CP}+\mathrm{EE}+\mathrm{NDF}+\mathrm{MM}),($ MERTENS, 1997). 
The experimental design was completely randomized and statistical analyzes of the variables were performed by means of Bayesian inference described in Rossi (2011). It was considered that the response $\left(Y_{i}\right)$ follows normal distribution, that is, $Y_{i} \sim \mathrm{N}\left(\mu_{i} \sigma_{i}^{2}\right), i=1,2, \ldots, \mathrm{n}_{j}$ for $j$-th treatments. For each $\mu_{\mathrm{i}}$ and $\sigma_{\mathrm{i}}^{2}$ a priori non-informative distributions were considered respectively, $\mu_{i} \sim \mathrm{N}\left(0,10^{6}\right)$ and $\sigma_{i}^{2}$ $\sim$ Gamma $\left(10^{3}, 10^{3}\right)$. Multiple comparisons were performed between the a posteriori distributions of the mean and treatments which credibility intervals for the mean differences do not include the value 0 were considered as different at the level of $5 \%$ of significance. For linear regression $Y_{i}=\beta_{0}+\beta_{1}$ Treatment $+\varepsilon_{i}$, assuming $\varepsilon_{i} \sim \mathrm{N}\left(0, \sigma^{2}\right)$, the same specifications in the a priori distributions were used for the parameters.

Three Holstein steers, fitted with rumen cannula and an average weight of $420 \pm 30 \mathrm{~kg}$ were used to determine ruminal degradability of DM and NDF degradability percentage. The animals were adapted with sugarcane silage and concentrate for 10 days on a diet that had roughage / concentrate ratio of 70:30 (VANZANT; COCHRAN; TITGEMEYER, 1998).

The ruminal degradability of the dry matter, the silage and their degradation rates were estimated by the in situ technique, using nylon bags measuring 10 $\mathrm{cm} \times 20 \mathrm{~cm}$, with pore diameters of 53 microns, as recommended by Vanzant, Cochran and Titgemeyer (1998). Sample of approximately $6 \mathrm{~g}$ were placed in each bag, closing them and binding them with rubber bands. On incubation days, the bags were attached to a stainless steel cylindrical bar $(600 \mathrm{~g})$ suspended by a $60 \mathrm{~cm}$ chain attached to a nylon rope tied to the external part of the ruminal fistula.

Incubation times were $0,2,6,12,24,48,72$ and $96 \mathrm{~h}$ and the nylon bags were placed in the rumen in order to attain the desired times, and removed all at once.

After being removed from the rumen the nylon bags were immersed in water and ice to stop microbial fermentation. Then, they were washed in running water for 10 minutes together with the nylon bags related to the time 0 of incubation. After these procedures, all the nylon bags were placed in a forced air drying oven at $55^{\circ} \mathrm{C}$ for $72 \mathrm{~h}$ and then weighed to obtain the weight of the dry residue. In sequence the NDF content (VAN SOEST; ROBERTSON; LEWIS, 1991) of the dry residue was analyzed and the disappearance percentage of the neutral detergent fiber was determined.

The DM degradability was adjusted by nonlinear regression, which predicts the potential degradability $(y=P D)$ of food through the model proposed by Mehrez and Ørskov (1977), as follows:

$$
\text { Equation (1): } \mathrm{y}_{\mathrm{ijk}}=\mathrm{a}_{\mathrm{ik}}+\mathrm{b}_{\mathrm{ik}}\left(1-\mathrm{e}^{-\mathrm{c}_{\mathrm{ik}} \mathrm{t}_{\mathrm{j}}}\right)
$$

i-animal : $1,2, \ldots, \mathrm{N}$;

j-time : $1,2, \ldots, \mathrm{J}$;

k-treatment : $1,2, \ldots, \mathrm{K}$;

$\mathrm{y}$ is the percentage of degraded nutrient after time $\mathrm{t}$ (in hours);

a is the intercept of the curve or the soluble fraction of the material contained in the nylon bag;

$\mathrm{b}$ is the potentially degradable fraction of the material in nylon bag after time 0 ;

$\mathrm{c}$ is the degradation fractional rate constant of the potentially degradable fraction $b$;

$\mathrm{t}$ is the incubation time in the rumen, in hours.

To estimate the effective degradability (ED) the Ørskov and McDonald (1979) model was used:

$$
\text { Equation (2), } E D=a+\frac{b c}{c+k^{*}}
$$

in which $\mathrm{k}^{*}$ is the rate of solids passage in the rumen, which value was set at 2, 5 and $8 \%$ per hour.

The modeling follows the suggestion of a Bayesian approach (ROSSI et al., 2010; ROSSI, 
2011), which considered that the observations follow a Normal distribution, in other words, $y_{i} \sim N\left(f\left(t_{i}\right) ; \sigma_{e}^{2}\right)$ in which $f\left(t_{i}\right)$ is the non linear function proposed in (1). For the $a$ and $b$ parameters, a priori non-informative normal distributions were considered, that is: $a, b \sim \mathrm{N}\left(0,10^{6}\right)$ and $c$, a Gamma distribution also non-informative restricted in the interval $(0,1)$, that is: $c \sim \operatorname{Gamma}\left(10^{3}, 10^{3}\right) \mathrm{I}_{(0,1)}$. For $\sigma_{\mathrm{e}}^{2}$ a Gamma distribution was assumed, that is, $\sigma_{\mathrm{e}}^{2} \sim \operatorname{Gamma}\left(10^{3}, 10^{3}\right)$. The attainment of the $a$ posteriori marginal distributions for the parameters was through the BRugs package program (R DEVELOPMENT CORE TEAM, 2012).

For each parameter, 310,000 values were generated in a MCMC (Markov Chain Monte Carlo) process, assuming a sampling discard period of 10,000 initial values, thus the final sample obtained in leaps of every 30 values, contains 10,000 generated values. The convergence of the chains was verified by the coda package of the program R, by the Heidelberger and Welch (1983) criterion.
To compare treatments, multiple comparisons were made between posteriori distribution of the averages of the parameters ofinterest. The treatments for which credibility intervals for the mean differences did not include zero were considered as different at the level of 5\% significance.

\section{Results and Discussion}

The dry matter (DM), crude protein (CP), neutral detergent fiber (NDF), acid detergent fiber $(\mathrm{ADF})$, ether extract (EE), mineral matter (MM), non-fiber carbohydrates (NFC) total digestible nutrients $(\mathrm{TDN})$ were influenced $(\mathrm{P}<0.05)$ by the addition of glycerin levels to the silage. A difference is observed $(\mathrm{P}<0.05)$ in the DM content of the sugarcane control silages and in the ones with 5\% of glycerin in relation to other levels (Table 1).

Comparing the percentage increase of the dry matter of the sugarcane silage with $20 \%$ of glycerin to control, an increase of $47 \%$ in the DM was observed and of $19.82 \%$ in relation to the silage containing $15 \%$ of glycerin.

Table 1. Bayesian estimation averages for the chemical composition of the sugarcane silage containing levels of 0,5 , 10,15 and $20 \%$ of glycerin.

\begin{tabular}{ccccccccc}
\hline \multirow{2}{*}{$\begin{array}{c}\text { Glycerin } \\
\text { levels }\end{array}$} & \multicolumn{7}{c}{ Averages (\%) } \\
\cline { 2 - 8 } & DM & CP & NDF & ADF & EE & MM & NFC* & TDN** $^{* *}$ \\
\hline 0 & $26.76 \mathrm{c}$ & $4.02 \mathrm{a}$ & $77.12 \mathrm{a}$ & $49.91 \mathrm{a}$ & $1.15 \mathrm{a}$ & $3.26 \mathrm{c}$ & $17.19 \mathrm{c}$ & $43.73 \mathrm{e}$ \\
$5 \%$ & $28.23 \mathrm{c}$ & $2.75 \mathrm{~b}$ & $65.64 \mathrm{~b}$ & $41.97 \mathrm{~b}$ & $1.05 \mathrm{ab}$ & $4.11 \mathrm{~b}$ & $26.46 \mathrm{~b}$ & $50.22 \mathrm{~d}$ \\
$10 \%$ & $31.59 \mathrm{~b}$ & $2.94 \mathrm{ab}$ & $59.19 \mathrm{c}$ & $36.90 \mathrm{c}$ & $1.11 \mathrm{ab}$ & $4.52 \mathrm{ba}$ & $32.23 \mathrm{ba}$ & $63.56 \mathrm{c}$ \\
$15 \%$ & $33.00 \mathrm{~b}$ & $2.51 \mathrm{~b}$ & $55.40 \mathrm{~cd}$ & $34.18 \mathrm{c}$ & $1.01 \mathrm{ab}$ & $5.14 \mathrm{ba}$ & $35.95 \mathrm{ba}$ & $60.58 \mathrm{~b}$ \\
$20 \%$ & $39.54 \mathrm{a}$ & $2.72 \mathrm{~b}$ & $50.06 \mathrm{~d}$ & $30.03 \mathrm{c}$ & $0.80 \mathrm{~b}$ & $5.44 \mathrm{a}$ & $41.06 \mathrm{a}$ & $63.62 \mathrm{a}$ \\
\hline
\end{tabular}

a, b, c, d averages followed by different letters are statistically different by Bayesian comparisons $(\mathrm{P}<0.05)$. Linear regressions: Dry Matter (DM: y = 25.76 + 0.61 T; R2 =0.78), Crude Protein $(C P: y=3.55+(-0.06) T$; R2 $=0.29$ ns); Neutral Detergent Fiber $\left(\mathrm{NDF}: \mathrm{y}=74.36+(-1.29) \mathrm{T} ; \mathrm{R}^{2}=0.84\right)$; Acid Detergent Fiber $\left(\mathrm{ADF}: \mathrm{y}=48.11+(-0.95) \mathrm{T} ; \mathrm{R}^{2}=0.81\right)$; Ether Extract $($ EE: $\mathrm{y}=1.17+$ $\left.(-0.02) \mathrm{T} ; \mathrm{R}^{2}=0.17 \mathrm{~ns}\right)$; Mineral Matter $\left(\mathrm{MM}: \mathrm{y}=3.41+0.11 \mathrm{~T} ; \mathrm{R}^{2}=0.71\right)$; Non-fiber Carbohydrates $\left(\mathrm{NFC}: \mathrm{y}=19.14+1.14 \mathrm{~T} ; \mathrm{R}^{2}=\right.$ 0.87 ) and Total Digestible Nutrients (TDN: $\left.\mathrm{y}=46.32+1.00 \mathrm{~T} ; \mathrm{R}^{2}=0.23\right) .{ }^{*}$ Estimated non-fiber carbohydrates (NFC), calculated by the equation $\mathrm{NFC}=100-(\mathrm{CP}+\mathrm{EE}+\mathrm{MM})(\mathrm{MERTENS}, 1997){ }^{* *}$ Estimated total digestible nutrients $(\mathrm{TDN})$, calculated using the equation TDN $(\%)=\operatorname{IVDDM}+(1.25 * \mathrm{EE})-\mathrm{MM},(\mathrm{VAN}$ SOEST, 1994). 
This variation in the DM content of the silage can be explained by the high density $\left(1.2613 \mathrm{~g} . \mathrm{cm}^{-3}\right)$ of the glycerin, in addition to the hygroscopic properties that allow the connection with the water molecules of the ensiled material, increasing the density of the silage DM (IUPAC, 1997).

There was a reduction of the mean values of the silage $\mathrm{CP}$ compared to the control silage, fact influenced by the glycerin composition, which has no nitrogenous substances, exercising therefore dilutive effect.

Avila et al. (2008) evaluated the protein content of the sugarcane silages with and without inoculant (Lactobacillus buchneri) and observed mean values of $2.58 \%$ of CP for silages without inoculant and $2.56 \%$ of $\mathrm{CP}$ for the inoculated silages, similar values to those obtained in this study (Table 1).

The percentage of NDF and ADF in the sugarcane silages with glycerin decreased $(\mathrm{P}<0.05)$ when compared to the control silages, a result influenced by the treatment. Comparing the control silage to the silage with $20 \%$ of glycerin, a reduction of $35 \%$ of the NDF content was found.

The sugarcane silages with $20 \%$ glycerin, in this study, showed better chemical composition, higher DM content (47\%), lower levels of ADF (39.8\%) and NDF (35\%) compared to the sugarcane silage without glycerin. These results are in agreement with those found by Santos et al. (2014) who observed that the inclusion of glycerin was effective in reducing the NDF content and increase the DM content of sugar cane silages, proving to be a plausible strategy to compensate for the energy loss in the sugarcane ensiling. This change in the sugarcane chemical composition can mean an increase in quality, since, according to Van Soest (1994), the values of the cell wall constituents above 55-60\% in DM negatively correlate with the DM intake and digestibility.

As glycerin was added to the silages a dilution effect was observed with decreasing values of EE ( $\mathrm{P}<0.05)$ compared to control by the low amount of lipids of the semi-purified glycerin Südekum
(2008). In the crude glycerin purification process the separation of glycerol is done and the removal of minerals, methanol and fatty acids. In the semi-purified glycerin (glycerol $\pm 80 \%$ ), there are small amounts of non-esterified fatty acids that are supernatants when the liquid is at rest which facilitates their removal along with other impurities (OOI et al., 2004). On the other hand, the lower lipid content does not limit the inclusion of glycerin in the silage for ruminants for not offering deleterious effects on rumen fermentation or cause bio-hydrogenation by rumen microorganisms.

MM values rose $(\mathrm{P}<0.05)$ and were influenced by the inclusion of glycerin. This result occurred due to the ash $(7.4 \%)$ and sodium $(1.3 \%)$ content of the glycerin used in this experiment. The high mineral content of the glycerin is derived from the residues in the transesterification process and the glycerin from biodiesel purification with sodium methylate, acids and bases. Semi-purified glycerin contains mineral elements such as phosphorus, sulfur, magnesium, calcium and sodium, which may be used as a substrate by the rumen microorganisms during the fermentation processes (THOMPSON; $\mathrm{HE}, 2006)$. The increase in the MM content in the sugarcane silages is a positive factor, considering that sugarcane is naturally low in minerals.

The NFC content increased with the inclusion of glycerin $(\mathrm{P}<0.05)$ contributing to the quality of the roughage in rapidly fermentable carbohydrates (Table 1$)$. An increase $(\mathrm{P}<0.05)$ in the energy density of the sugarcane silages was observed at levels of $5,10,15$ and $20 \%$ of glycerin. The estimated TDN increased influenced by the addition of glycerin to the silage, reaching 20 percentage points in silage with $20 \%$ of glycerin in relation to the control treatment. Südekum (2008) estimated at 1982 to 2269 Mcal / kg of net energy for glycerin from biodiesel lactation. For this reason, the glycerin contributed positively to the energy increase of the ensiled material.

The improvement in the chemical composition of the sugarcane silage with glycerin occurred by 
the NFC and TDN increment and by the reduction in then NDF and ADF content, results that can offset quality losses in the ensiling processes and in the supply to animals after the opening, enabling the glycerin as an additive capable of enriching the ensiled material.

The IVDDM for the silages with 10, 15 and $20 \%$ of glycerin was influenced by the treatment $(\mathrm{P}<0.05)$ with no difference between the levels 10 and $15 \%(\mathrm{P}>0.05)$ nor between the control and the silage with $5 \%$ of glycerin (Table 2 ).

The digestibility is used as a quality variable indicating the food proportion that is ready to be used by the animal (VAN SOEST, 1994). The decrease in the nutritional value of the ensiled sugarcane silage was reported by Alcantara et al. (1989), who observed a reduction in the IVDDM from $66.4 \%$ to $55.3 \%$ when compared to the sugarcane in natura. In this study an increase $(\mathrm{P}<0.05)$ in the IVDDM of the sugarcane silage was observed with $5,10,15$ and $20 \%$ of glycerin at $16.6,23.3,41.5$ and $50.8 \%$ when compared to the control. Kitessa et al. (1999) observed that the nutrients digestibility is closely related to the energy content of the food given to ruminants. Possibly, the IVDDM results observed (Table 2) are related to the increased energy content and improved digestibility of the ensiled materials.

Table 2. Bayesian mean estimates for in vitro digestibility of dry matter (IVDDM) and in vitro digestibility of the cell wall (IVDCW) of the sugarcane silage with $0,5,10,15$ and $20 \%$ of glycerin.

\begin{tabular}{|c|c|c|c|c|c|}
\hline \multirow{2}{*}{ Digestibility } & \multicolumn{5}{|c|}{ Glycerin level } \\
\hline & 0 & $5 \%$ & $10 \%$ & $15 \%$ & $20 \%$ \\
\hline IVDDM (\%) & $45.54 \mathrm{c}$ & $53.03 \mathrm{c}$ & $56.04 \mathrm{bc}$ & $64.45 \mathrm{ab}$ & $68.70 \mathrm{a}$ \\
\hline IVDCW(\%) & $27.38 \mathrm{~b}$ & $29.29 b$ & $37.28 \mathrm{a}$ & $37.11 \mathrm{a}$ & $41.52 \mathrm{a}$ \\
\hline
\end{tabular}

a, b, c Averages followed by different letters in the lines are statistically different using Bayesian comparisons $(\mathrm{P}<0.05)$. Linear regression: (IVDDM: $\mathrm{y}=48.27+1.13 \mathrm{~T} ; \mathrm{R}^{2}=0.30 \mathrm{NS}$ ) (IVDCW: $\mathrm{y}=27.30+0.72 \mathrm{~T}, \mathrm{R}^{2}=0.62$ ).

The in vitro digestibility of the cell wall increased $(\mathrm{P}<0.05)$ with the inclusion of glycerin (Table 2), with no difference among the levels of 10 , 15 and $20 \%$. Comparing the control silage and the silage with $20 \%$ of glycerin, an increase of $51.64 \%$ in the IVDCW was observed, a positive result when it comes to sugarcane which traditionally presents low incidence of digestibility. Research works have shown that there are limitations in the sugarcane consumption, primarily by the low digestibility of the NDF, reducing consumption by rumen filling (MAGALHÃES et al., 2006), as a result of indigestible fiber accumulation (RODRIGUEZ, 1995).
It is likely that the new nutrient proportions observed in the sugarcane silages with glycerin in this study, like the reduction of the NDF and ADF (Table 1) and the increase of the IVDCW (Table 2), could provide increased dry matter intake (DMI), and possibly better utilization by the animals.

The readily degradable portion of sugarcane $(\mathrm{P}$ $<0.05$ ), in the rumen (a), as well as the insoluble and potentially degradable fraction (b) were influenced by the levels of glycerin in the silage (Table 3 ). 
Table 3. Bayesian mean estimates for the model parameters and effective degradability of dry matter (ED) for passage rates of 2, 5 and $8 \%$ per hour of sugarcane silage with $0,5,10,15$ and $20 \%$ of glycerin.

\begin{tabular}{cccccccc}
\hline \multirow{2}{*}{ Glycerin } & \multicolumn{7}{c}{ Parameters } \\
\cline { 2 - 8 } 0 & $a(\%)$ & $b(\%)$ & $c(\% / \mathrm{h})$ & ED k=2\% & ED k=5\% & ED k=8\% & $\sigma_{\mathrm{e}}$ \\
$5 \%$ & $17.04 \mathrm{a}$ & $61.37 \mathrm{a}$ & $1.24 \mathrm{bc}$ & $40.96 \mathrm{~d}$ & $29.78 \mathrm{e}$ & $25.75 \mathrm{e}$ & 6.43 \\
$10 \%$ & $51.01 \mathrm{~b}$ & $55.00 \mathrm{a}$ & $1.23 \mathrm{bc}$ & $55.37 \mathrm{c}$ & $45.40 \mathrm{~d}$ & $41.79 \mathrm{~d}$ & 5.49 \\
$15 \%$ & $33.14 \mathrm{bc}$ & $1.65 \mathrm{c}$ & $66.88 \mathrm{~b}$ & $60.54 \mathrm{c}$ & $57.95 \mathrm{c}$ & 6.75 \\
$20 \%$ & $60.96 \mathrm{~d}$ & $26.62 \mathrm{bd}$ & $4.04 \mathrm{a}$ & $72.08 \mathrm{~b}$ & $66.76 \mathrm{~b}$ & $64.09 \mathrm{~b}$ & 6.93 \\
\hline
\end{tabular}

$\mathrm{a}, \mathrm{b}, \mathrm{c}, \mathrm{d}$, e Averages followed by different letters are statistically different by Bayesian comparisons $(\mathrm{P}<0.05)$. a $=$ readily degradable portion in the rumen; $\mathrm{b}=$ insoluble fraction but potentially degradable; $\mathrm{c}=$ constant rate of the fraction degradability $\mathrm{b} / \mathrm{h} . \mathrm{ED}=$ effective degradability of the dry matter. $\mathrm{k}=$ is the passage rate of solids in the rumen, which value was set at 2,5 and $8 \%$ per hour. $\sigma=$ error standard deviation.

Aroeira, Lopes e Dayrell (1996) reported that effective degradability (ED) of a food can be considered as the energy digested in the rumen and, therefore, the intake of foods with higher degradability provides more energy available to the microorganisms.

The fiber constituents of the forages are of great importance, because they compose the major fraction of the plant dry matter and constitute the less digested fraction of the plant in the digestive tract and the slowest digested in the in the rumen (THIAGO; GILL, 1993). The typical situation for diets based on sugar cane relate to the low pass rate and the high retention time of this food, and because of that, the low MS intake (MAGALHÃES et al., 2006). Even with a higher passage rate, the dry matter ED at 2, 5 and $8 \% / \mathrm{h}$ of the silages with $5,10,15$ and $20 \%$ of glycerin showed better results compared to the control treatment $(\mathrm{P}<$ 0.05). The data (Table 3 ) show the silage with $20 \%$ of glycerin with the highest percentage of readily degradable portion in the rumen $(a)$, a reduction in the insoluble fraction but potentially degradable $(b)$, combined with the best constant degradability rate of the fraction $b(c \% / \mathrm{h})$. The results observed in the sugarcane silages with glycerin confer different profile to the forage, with higher degradability and passage rate, which might provide greater DM intake by reducing the percentage of ADF and NDF caused by the addition of glycerin. Thus, it can be said that the highest nutrient degradability of silages with glycerin indicate the highest utilization capacity of food by animals compared to control.

Figure 1 shows that the dry matter disappearance was higher as the levels of glycerin increased.

Even in the early hours of incubation, the DM disappearance was high, possibly due to high solubility of glycerin in the rumen environment, highlighting the level with $20 \%$ glycerin which reached higher disappearance compared to the others in time of $96 \mathrm{~h}$ of incubation.

In Figure 2 it is shown that, in the initial periods, the sugarcane silages with and without glycerin showed very similar disappearance rates, and from $2 \mathrm{~h}$ of incubation on, the disappearance rate of the NDF in the silages with 10,15 and $20 \%$ of glycerin remained higher than those with 0 and $5 \%(\mathrm{P}<0.05)$ until 96 hours of incubation. 
Figure 1. Rumen Dry matter of the sugarcane silage disappearance curves, for the levels of $0,5,10,15$ e $20 \%$ of glycerin, observed in the incubation times $0,2,6,12,24,48,72$ and $96 \mathrm{~h}$.

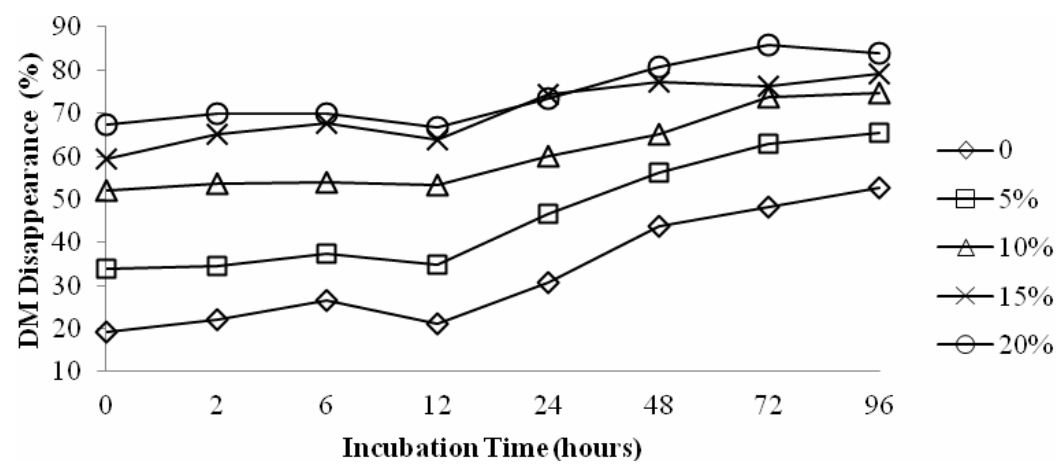

Figure 2. NDFof the sugarcane silage disappearance curves, for the levels of $0,5,10,15$ and $20 \%$ of glycerin, observed in the incubation times $0,2,6,12,24,48,72$ and $96 \mathrm{~h}$.

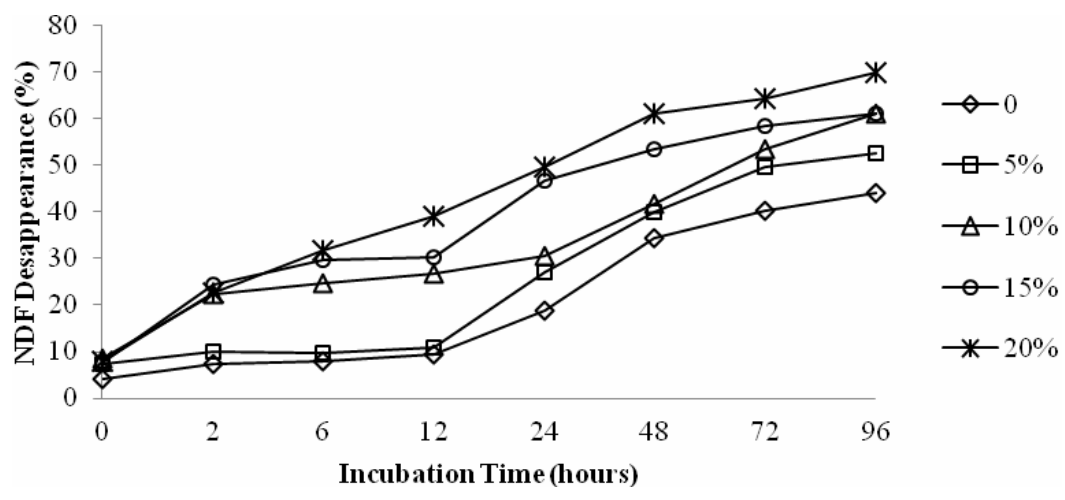

It appears that, up to $12 \mathrm{~h}$ of incubation, the control silage and with $5 \%$ of glycerin showed similar degradation and after $12 \mathrm{~h}$ the silage with $5 \%$ of glycerin showed higher disappearance than the control treatment until 96h of incubation.

Possibly, the silages with 10,15 and $20 \%$ of glycerin provided higher amount of energy to the rumen microbiota, increasing NDF degradation. This difference between the sugarcane silages with and without glycerin can constitute an important factor to affect animal consumption, increasing the passage rate and dry matter intake.

In the evaluation of aerobic stability of the silages, it is observed that after $24 \mathrm{~h}$, the $\mathrm{pH}$ of control silage showed an elevation, which was repeated in the measurements taken at 48, 72, 96 and $120 \mathrm{~h}$, a different reaction to that observed in the silages with glycerin (Figure 3). 
Figure 3. $\mathrm{pH}$ curves of the sugarcane silage for the levels of $0,5,10,15$ and $20 \%$ of glycerin observed at $0,24,48$, 72,96 and $120 \mathrm{~h}$.

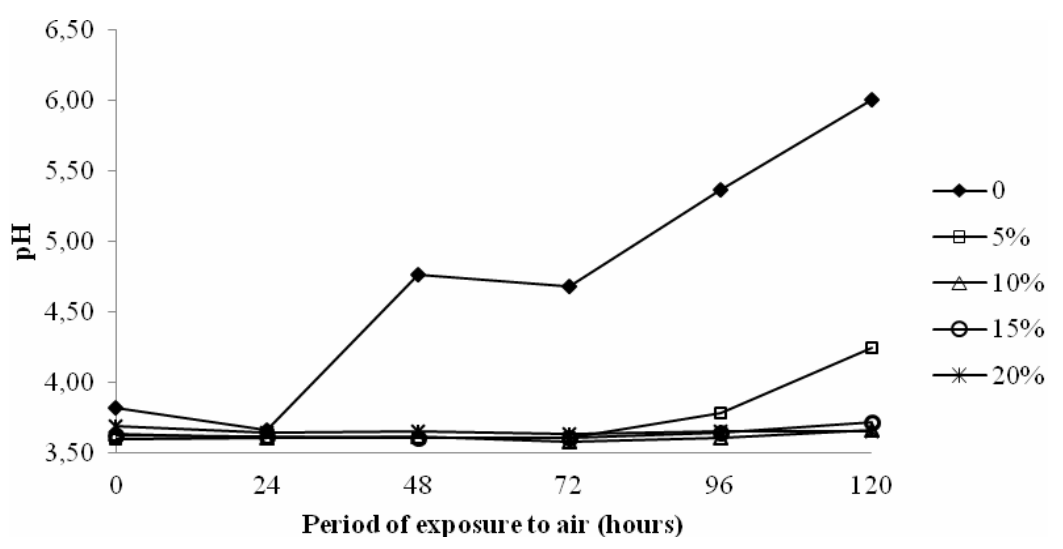

The $\mathrm{pH}$ values curve behavior shows that during the period of exposure to air, the sugarcane silages with 10,15 and $20 \%$ of glycerin maintained low $\mathrm{pH}$ for a longer time $(\mathrm{P}<0.05)$. The $\mathrm{pH}$ value rises after opening the silo, when organic acids that preserve the silage are consumed by micro-organisms (PAHLOW et al., 2003).

The treatment with $5 \%$ of glycerin remained with low $\mathrm{pH}$ until the observation conducted at $96 \mathrm{~h}$ of exposure to air, indicating increased stability of the silage. In the experiment of Santos et al. (2014) the differences in $\mathrm{pH}$ values between silages with and without glycerin occurred only after 120 hours of exposure to air when it was observed that the silage without the addition of glycerin, showed higher $\mathrm{pH}$.

Jobim and Gonçalves (2003) alerted to the deleterious effects of oxygenation of the ensiled mass, since the oxygen promotes the action of spoilage microorganisms and a reduction of soluble sugars and organic acids, resulting in increased $\mathrm{pH}$ and decreased digestibility and energy content. Consequently, the deteriorated silages can lead to great economic losses and low animal performance. $\mathrm{pH}$ results obtained indicate that even when exposed to air the glycerin was effective in preserving organic acids present in the sugarcane silage maintaining the acidity between 3.5 and 4 for a longer time.
Figure 4 shows the variation of the temperature of the ensiled mass (TEM) of the sugarcane silage with $0,5,10,15$ e $20 \%$ of glycerin measured at 0 , $24,48,72,96$ and $120 \mathrm{~h}$ after the silo opening.

An increase in temperature of the ensiled mass was observed in all silages as the silos were opened (Figure 4). The aerobic stability of the control silage was broken in the first $24 \mathrm{~h}$ confirmed by the TEM difference in relation to the ambient temperature. Starting at $48 \mathrm{~h}$, there was a stability breakage in all treatments with the major difference between TEM and ambient temperature. It is also seen that the silage with 15 and $20 \%$ of glycerin, starting at 48 hours showed a decrease in TEM, indicating that the microbiological activities were less intense. The lowest aerobic stability was observed in the control treatment, with a great increase of TEM after exposure to air, over the observation period ranging from $18.75^{\circ} \mathrm{C}(0 \mathrm{~h})$ to $26.5^{\circ} \mathrm{C}(120 \mathrm{~h})$ to an average ambient temperature of $18.5^{\circ} \mathrm{C}$, indicating that in this period there was intense microbiological activity. The temperature rise is a result of the balance between the heat rates produced by microbial activity and heat losses by conduction, radiation, convection and evaporation and is directly related to the dry matter oxidation which cause losses in the form of carbon dioxide (HILL; LEAVER, 2002). 
Figure 4. Curves of the sugarcane silage temperature with $0,5,10,15$ and $20 \%$ of glycerin and curves of ambient temperature (TA) measured after the silo opening at 0,24, 48, 72, 96 and $120 \mathrm{~h}$.

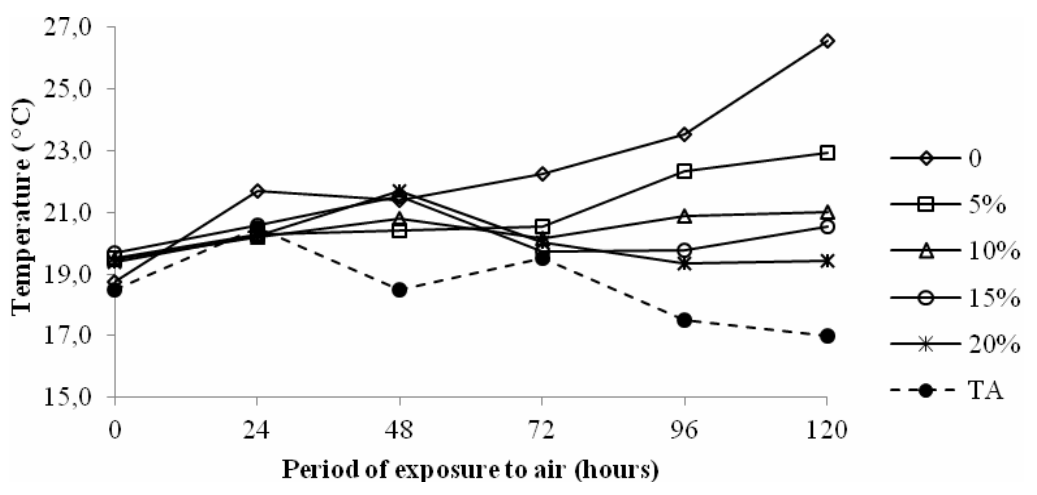

The main microorganisms related to the deterioration of the silage exposed to air are the fungi, especially the yeasts and the bacteria of the Bacillus genre (WOOLFORD, 1990).

Thus, the results which appear in Figures 3 and 4 indicate that the level of glycerin inclusion in the sugarcane ensilage influenced the chemical composition of the silages, resulting in higher aerobic stability compared to the control silages. A longer exposure to air for silage with 10, 15 and 20\% of glycerin was needed to register increases in EMT and $\mathrm{pH}$ elevation in the 120 hours of observation.

Santos et al. (2014) found that the sugar cane silage with $9 \%$ of glycerin reduced the production of lactic acid and tended to decrease the concentration of ethanol and glycerin dosage did not affect aerobic stability, different result found in this study.

According to these results, glycerin was, possibly, able to reduce the silage fermentation in the aerobic phase, after the opening, since it is not a suitable substrate for the development of spoilage microorganisms

\section{Conclusion}

It is concluded that glycerin proved to be an efficient additive for the sugarcane silage, able to enrich the energy density, increase ruminal degradability and digestibility of the silage, besides improving the aerobic stability of the ensiled material.

This study was approved by the Ethics Committee on Animal Use in Experimentation - CEAE of the State University of Maringa PR UEM on $04 / 03 / 2009$, No $009 / 2009$ and $020 / 2009$ approval.

\section{References}

ALCÂNTARA, E.; AGUILERA, A.; ELLIOTT, R.; SHIMADA, A. Fermentation and utilization by lambs of sugarcane harvest fresh and ensiled with and without Noah: 4. Ruminal kinetics. Animal Feed Science and Technology, Amsterdam, v. 23, n. 4, p. 323-331, 1989.

ASSOCIATION OF OFFICIAL ANALYTICAL CHEMISTRY - AOAC. Official methods of analysis. $15^{\text {th }}$ ed. Washington D.C.: AOAC Internacional, 1990. $1141 \mathrm{p}$.

AROEIRA, L. J. M.; LOPES, F. C. F.; DAYRELL, M. S. Degradabilidade de alguns alimentos no rúmen de vacas Holandês/Zebu. Revista da Sociedade Brasileira de Zootecnia, Viçosa, MG, v. 25, n. 6, p. 1178-1186, 1996.

ÁVILA, C. L. S.; PINTO, J. C.; SUGAWARA, M. S.; SILVA, M. S.; SCHWAN, R. F. Qualidade da silagem de cana-de-açúcar inoculada com uma cepa de Lactobacillus buchneri. Acta Scientiarum. Animal Sciences, Maringá, v. 30, n. 3, p. 255-261, 2008. 
CHERNEY, J. H.; CHERNEY, D. J. R. Assessing silage quality. In: BUXTON, D. R.; MUCK, R. E.; HARRISON, J. (Ed.). Silage science and technology. Madison, Wisconsin: American Society of Agronomy, 2003. p. 141-198.

GOERING, H. K.; VAN SOEST, P. J. Forage fiber analyses (Apparatus, regents, procedures, and some applications). Agriculture Handbook 379. Washington: United States Department of Agriculture, 1970. 20 p.

HEIDELBERGER, P.; WELCH, P. Simulation run length control in the presence of an initial transient. Operations Research, Baltimore, v. 31, n. 6, p. 1109-1144, 1983.

HILL, J.; LEAVER, J. D. Changes in chemical composition and nutritive value of urea treated whole crop wheat during exposure to air. Animal Feed Science and Technology, Amsterdam, v. 102, n. 1-4, p. 181-195, 2002.

INTERNATIONAL UNION OF PURE AND APPLIED CHEMISTRY - IUPAC. Compendium of chemical terminology 1997. $2^{\text {nd }}$ ed. In: MCNAUGHT, A. D.; WILKINSON, A. (Ed.). The gold book. Blackwell Scientific Publications, Oxford, 1997. 464 p. Available at: <http://goldbook.iupac.org>. Accessed at: 15 mar. 2007.

JOBIM, C. C.; GONÇALVES, G. D. Microbiologia de forragens conservadas. In: REIS, R. A.; BERNARDES, T. F.; SIQUEIRA, G. R.; MOREIRA, A. L. (Ed.). Volumosos para produção de ruminantes: valor alimentício de forragens. Jaboticabal: FUNEP, 2003. p. $1-26$.

KITESSA, S.; FLINN, P. C.; IRISH, G. G. Comparison of methods used to predict the in vivo digestibility of feeds in ruminants. Australian Journal of Agricultural Research, Victoria, v. 50, n. 5, p. 825-841, 1999.

MAGALHÃES, A. L. R.; CAMPOS, J. M. S.; CABRAL, L. S.; MELLO, R.; FREITAS, J. A.; TORRES, R. A.; VALADARES FILHO, S. C.; ASSIS, A. J. Cana-deaçúcar em substituição à silagem de milho em dietas para vacas em lactação: parâmetros digestivos e ruminais. Revista Brasileira de Zootecnia, Viçosa, v. 35, n. 2, p. 591-599, 2006.

McDONALD, P.; HENDERSON, A. R.; HERON, S. J. E. The biochemistry of silage. $2^{\text {th }}$ ed. Marlow: Chalcomb Publishing, 1991. $340 \mathrm{p}$.

MEHREZ, A. Z.; ØRSKOV, E. R. A study of the artificial fibre bag technique for determining the digestibility of feeds in the rumen. The Journal of Agricultural Science, Cambridge, v. 88, n. 3, p. 645-650, 1977.
MERTENS, D. R. Creating a system for meeting the fiber requirements of dairy cows. Journal of Dairy Science, Champaign, v. 80, n. 7, p. 1463-1481, 1997.

NUSSIO, L. G.; RIBEIRO, J. L.; PAZIANI, S. F.; NUSSIO, C. B. Fatores que interferem no consumo de forragens conservadas. In: SIMPÓSIO SOBRE VOLUMOSOS NA PRODUÇÃO DE RUMINANTES, 1., 2003, Jaboticabal. Anais... Jaboticabal: FUNEP, 2003. p. $27-50$.

OOI, T. L.; YONG, K. C.; HAZIMAH, A. H.; DZULKEFLY, K.; WAN-YUNUS, W. M. Z. Glycerol residue - a rich source of glycerol and medium chain fatty acids. Journal of Oleo Science, Utsunomiya, v. 53, n. 1, p. 29-33, 2004.

ØRSKOV, E. R.; McDONALD, I. The estimation of protein degradability in the rumen from incubations measurements weighted according to the rate of passage. Journal of Agricultural Science, Cambridge, v. 92, n. 2, p. 499-503, 1979.

PAHLOW, G.; MUCK, R. E.; DRIEHUIS, F.; OUDE ELFERINK, S. J. W. H.; SPOELSTRA, S. F. Microbiology of ensiling. In: BUXTON, D. R.; MUCK, R. E.; HARRISON, J. H. (Ed.). Silage science and technology. Madison: American Society of Agronomy, 2003. p. 31-93.

PEDROSO, A. F.; NUSSIO, L. G.; PAZIANI, S. F.; LOURES, D. R. S.; IGARASI, M. S.; COELHO, R. M.; PACKER, I. M.; HORII, J.; GOMES, H. L. Fermentation and epiphytic microflora dynamics in sugar cane silage. Scientia Agrícola, Piracicaba, v. 62, n. 5, p. 427-432, 2005.

R DEVELOPMENT CORE TEAM. R: A language and environment for statistical computing. $\mathrm{R}$ Foundation for Statistical Computing, Vienna, Austria. 2012. Available at: <http://www.R-project.org $>$. Accessed at: 15 nov. 2012.

ROSSI, R. M. Introdução aos métodos Bayesianos na análise de dados zootécnicos com uso do WinBUGS e R. Maringá: Eduem, 2011. 191 p.

ROSSI, R. M.; GUEDES, T. A.; MARTINS, E. N.; JOBIM, C. C. Bayesian analysis for comparison of nonlinear regression model parameters: an application to ruminal degradability data. Revista Brasileira de Zootecnia, Viçosa, v. 39, n. 2, p. 419-424, 2010.

SANTOS, P.; CARVALHO, B. F.; ÁVILA, C. L. S.; DIAS JÚNIOR, G. S.; PEREIRA, M. N.; SCHWAN, R. F. Glycerin as an additive for sugarcane silage. Annals of Microbiology, Berlin, v. 64, p. 1-10, 2014. Available at: $<$ http://link.springer.com/article/10.1007/s13213-0140993-x>. Accessed at: 6 jan. 2015. 
SANTOS, P.; CARVALHO, B. F.; ÁVILA, C. L. S.; DIAS JÚNIOR, G. S.; PEREIRA, M. N.; SCHWAN, R. F. Glycerin as an additive for sugarcane silage. Annals of Microbiology, v. 64, p. 1007/s13213, 2014. Available at: $<$ http://link.springer.com/article/10.1007/s13213-0140993- $\mathrm{x}>$. Accessed at: 6 jan. 2015.

SÜDEKUM, K. H. Co-products from biodiesel production. In: GARNSWORTHY, P. C.; WISEMAN, J. (Ed.). Recent advances in animal nutrition. Nottingham: Nottingham University Press, 2008. p. 210-219.

SIQUEIRA, G. R.; REIS, R.A.; SCHOCKENITURRINA, R. P.; BERNARDES, T. F.; PIRES, A. J. V.; ROTH, M. T. P.; ROTH, P. T. P. Associação entre aditivos químicos e bacterianos na ensilagem de cana-de-açúcar. Revista Brasileira de Zootecnia, Viçosa, MG, v. 36, n. 4, p. 789798, 2007.
THOMPSON, J. C.; HE, B. B. Characterization of crude glycerol from biodiesel production from multiple feedstocks. Applied Engineering in Agriculture, St. Joseph, v. 22, n. 2, p. 261-265, 2006.

VAN SOEST, J. P. Nutritional ecology of ruminant. $2^{\text {th }}$ ed. Ithaca: Cornell University Press, 1994. 476 p.

VAN SOEST, P. J.; ROBERTSON, J. B.; LEWIS, B. A. Methods for dietary fiber, neutral detergent fiber, and nonstarch polysaccharides in relation to animal nutrition. Journal of Dairy Science, Champaign, v. 74, n. 10, p. 3583-3597, 1991.

VANZANT, E. S.; COCHRAN, R. C.; TITGEMEYER, E. C. Standardization of in situ techniques for ruminant feedstuff evaluation. Journal of Animal Science, Champaign, v. 76, n. 10, p. 2717-2729, 1998. 
